Marileena Koskela \& Markus Vinnari (editors)

\title{
FUTURE OF THE CONSUMER SOCIETY
}

Proceedings of the Conference "Future of the Consumer Society" 28-29 May 2009, Tampere, Finland 
FFRC eBOOK 7/ 2009

\title{
FUTURE OF THE CONSUMER SOCIETY
}

\author{
Proceedings of the Conference \\ "Future of the Consumer Society" \\ 28-29 May 2009, Tampere, Finland
}

\section{Editors}

Marileena Koskela

Markus Vinnari 
Marileena Koskela, Project Manager

Turku School of Economics, Finland Futures Research Centre

marileena.koskela@tse.fi

Markus Vinnari, Research Scientist

University of J oensuu, Faculty of Social Sciences and Regional Studies

markus.vinnari@joensuu.fi

Copyright $\odot 2009$ Writers \& Finland Futures Research Centre, Turku School of Economics

ISBN 978-951-564-968-3

ISSN $\quad 1797-132$

Layout Katariina Yli-Heikkilä, Anne Arvonen

Finland Futures Research Centre

Turku School of Economics

Rehtorinpellonkatu 3, Fl-20500 Turku

Korkeavuorenkatu 25 A 2, FI-00130 Helsinki

Pinninkatu 47, Fl-33100 Tampere

Tel. +358 24814530

Fax +35824814630

www.tse. fi/ tutu

tutu-info@tse.fi, firstname.lastname@tse.fi

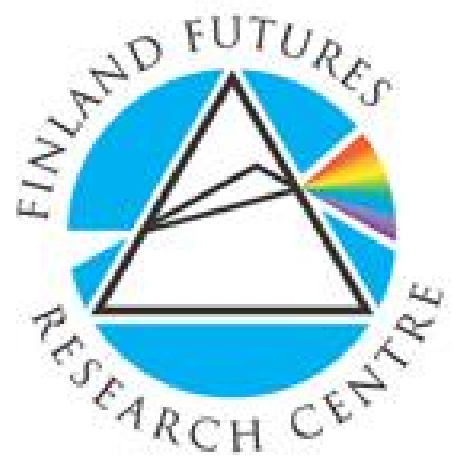




\title{
POLICIES TO PROMOTE SUSTAINABLE CONSUMPTION: FRAMEWORK FOR A FUTURE- ORIENTED EVALUATION
}

\author{
Eva Heiskanen ${ }^{a}$, Bettina Brohmann ${ }^{b}$, Norma Schönherr ${ }^{b}$ and Kristiina Aalto ${ }^{a}$ \\ ${ }^{a}$ National Consumer Research Centre, Finland \\ ${ }^{b}$ Institute for Applied Ecology (Öko-Institut), Germany
}

\begin{abstract}
ABST RACT - Governments are today developing policies to promote sustainable consumption, yet policy makers face many uncertainties about policy impacts. These include uncertainties about how policy instruments influence consumption patterns and about the impact of changes in consumption patterns on ecological, social and economic sustainability. An assessment of such impacts must account for the fact that consumer action is interlinked with the dynamic activities of other market players and the path-creating effects of technologies and systems of consumption and provision. Our paper presents an interdisciplinary conceptual framework for the assessment of policies to promote sustainable consumption. This assessment is conducted within a recently launched EC FP7-funded project called EUPOPP. It aims to use material flow analysis (MFA) to model the prospective impacts of best-practice policies on selected sustainability indicators in Europe.
\end{abstract}

\section{INTRODUCTION AND BACKGROUND}

The role of unsustainable consumption patterns in the deterioration of the global environment has been on the international policy agenda for more than a decade1. As a result, many European governments are developing strategies and policy instruments to promote sustainable consumption, and the European Commission has launched an Action Plan for Sustainable Consumption and Production².

The aim of the EUPOPP project (www.eupopp.net) is to analyse the sustainability impacts of the implementation of strategies and policy instruments for sustainable consumption in Europe. Our particular focus is on strategies and policy instruments ${ }^{3}$ that target the demand-side, i.e., private or organizational consumption, and products. There is great potential for resource efficiency improvements in these areas, but also great uncertainties about the capacities of public policy to influence them ${ }^{4}$.

In the EUPOPP project, we examine the impacts of sustainable consumption strategies and policy instruments by assessing the resultant improvements in economic, social, and environmental performance indicators against a business-as-usual scenario. Our focus is on two of the major fields of consumption in terms of environmental impacts 5 , i.e., housing and food.

The impacts of sustainable consumption strategies and policy instruments depend on a complex network of pathways. Firstly, strategies and policy instruments are realised in the form of various outputs, such as laws, regulations, programmes, schemes and implementation measures. Secondly, these outputs can have variable outcomes in terms of changes in consumer behaviour (i.e., the demand, use and disposal of products and services). Thirdly, the changes in consumer behaviour can have various impacts on environmental, economic and social sustainability ${ }^{6}$, which are mediated via changes in production patterns, changes in other consumption patterns, and changes in entire product systems.

This paper summarises the conceptual framework of the EUPOPP project and outlines the analytical approach adopted in the paper. Section II discusses the first pathway - the realization of policies in concrete instruments. Section III analyses the second pathway - from policy output to policy outcome in terms of changes in consumption patterns. Section IV discusses the pathway from consumption pattern changes to sustainability impacts. The concluding section draws some implications from this conceptual framework for empirical analysis. 


\section{FROM POLICY IDEA TO POLICY OUTPUT}

We can trace the pathways from policy idea to policy output by constructing intervention theories ${ }^{7}$, in $^{2}$ order to identify the conditions under which the policy ideas can lead to the expected outputs, and eventually, outcomes. Policy instruments are central here, and we define them the set of techniques of governance by which public and private institutional actors support and effect social change. For that purpose they usually involve the totality of existing forms of societal steering, comprising institutionalised societal self-regulation (cp. voluntary and procedural instruments), various forms of cooperation of public and private institutions (cp. economic and communication-based instruments), as well as mandatory regulation ${ }^{9,10}$. We have conducted a review of the most commonly applied policy instruments in the field of sustainable consumption in order to identify conditions for success and failure. These instruments include:

B regulatory instruments,

B economic instruments (including the special category of green public procurement)

B communication-based instruments (including the special category of labelling) and

B voluntary and procedural instruments.

Regulatory instruments oblige the addressees (citizens or organizations) to comply with govemment rules under threat of sanctions. Examples include bans, mandatory standards and permit requirements ${ }^{11}$. In order for these instruments to be successful, a number of context-related conditions must be fulfilled. A functioning legal system is required for establishing and implementing norms and standards. Appropriate physical, human and organizational resources need to be available to collect and assess information on the environmental issues at hand, as well as the capacity to decide on appropriate measures. During enforcement, governments have to be capable to oversee compliance and impose sanctions if necessary ${ }^{12}$. New instruments can thus gain significant benefits from existing regulatory capacities: for example, regulation and minimum standards are especially successful in the housing sector where sustainable consumption policies have been traditionally preceded by health and safety regulations ${ }^{13}$. Building codes are an example of an existing framework that has evolved to include measures to promote sustainable consumption. Apart from this, most environmental regulations have focused on production processes until now. Recently, attention in environmental policy has turned to products, and environmental product standards are a new instrument in the field of sustainable consumption. The EU EcoDesign Directive ${ }^{14}$ is an example of a product standard that is expected to have a significant impact on e.g., the energy-efficiency of electrical and electronic products.

Economic instruments involve the distribution or levying of resources, thus making certain behaviours more or less financially attractive. They encourage behaviour through the use of market signals rather than through explicit directives. These instruments can harness market forces, and if they are well designed and implemented, can encourage consumers and firms to undertake behaviour that is both in their own interests and in the interest of the environment. Ideally, economic instruments aimed at sustainable consumption correct for environmental externalities by ensuring that consumers face the full costs and benefits of their actions by altering the price signals faced by consumers ${ }^{15}$. For economic instruments, macroeconomic factors such as an adequate market infrastructure and the functionality of the market are likely to be relevant contextual factors. Moreover, the availability of sustainable products and technologies may determine whether an instrument is really capable of delivering a change in market structures or whether it is merely fiscal. This may occur if addressees do not perceive a way to substitute a taxed good or revert to altemative products. Also, economic instruments may entice addressees to attempt to avoid additional costs by reverting to illegal actions, such as dumping waste in the landscape instead of recycling. Other influential factors, with specific importance in energy efficiency improvement include energy price levels and the level of integration between energy efficiency policies and other sectoral policies ${ }^{16}$.

Among economic instruments, special attention is given to Green Public Procurement (GPP) defined as the process by which public authorities decide to purchase products, services and works with lower environmental impact all along their lifecycle compared to others with the same performance. GPP 
represents a kind of organizational strategy for greening the consumption by the public administrations at local, regional or national levels. It is a multifaceted instrument type, featuring characteristics of regulatory or economic instruments, and making use of labels and training, communication and information. At the EU level, GPP is one of the main levers for promoting sustainable production and consumption. For GPP, the review presented a list of contextual factors, including the level of political commitment in the public authority, the perception of the market availability of green products and services, the exchange of experience with other public authorities, the level of centralization or decentralization of purchasing decisions and the existence of a joint purchasing body for different public authorities ${ }^{17}$.

Communication-based policy instruments cover a broad range of activities aimed at influencing consumers through the transfer of knowledge, information, exhortation and/ or moral suasion without involving coercion or obligation of the addressees ${ }^{9}$. As the provision of information and education are very broad categories, a large variety of tools are available for the practical application of this instrument type, e.g., consumer information campaigns, consumer information centres, or feedback on consumption $^{18,19}$. An important contextual factor identified in our review was the reputation of the agencies providing information, which may be crucial for the addressees to accept the information as trustworthy.

Within communication-based policy instruments, labelling deserves special attention as a tool of sustainable consumption policy. Labels give information in a compact, simple form close to the point of purchase and are equally directed at manufacturers that are encouraged or obliged to label their products. If consumers, as well as private and public purchasers, are to take environmental criteria into consideration in their purchases, it is important that they can find easily understandable and credible criteria to enable them to distinguish the truly 'green' products. There are both mandatory and voluntary labelling schemes related to environmental information ${ }^{20}$, 21 . Important contextual features include consumer attitudes as well as multiple intervening factors between attitudes and behaviour, including abilities, opportunities, consumer empowerment and the social example set by others. Labelling also requires functioning communications from manufacturing through trade to final consumers, and each party in this chain needs to see the benefits of participating.

The traditional regulatory, economic, and communication-based instruments are supplemented by voluntary or procedural instruments. Based on $\mathrm{OECD}^{22}$, we define voluntary instruments as "policies that are designed to influence consumer and producer knowledge and, in tum, consumer and producer willingness to behave pro-environmentally". Four sub-types were identified: participatory mechanisms, voluntary commitments and initiatives, advisory schemes and provision of infrastructure ${ }^{23}$. Their success is linked to various context factors, including political and cultural views on public dialogue, the perceived added value of participation and the public's interest in participation. Moreover, the general regulatory and social context is even more important here than in the case of other instrument types. Pressure on societal actors to voluntarily adopt sustainable consumption and production patterns often depends on the threat of more restrictive instruments being introduced by the government ${ }^{24,25}$.

Our review of factors influencing success and failure will be complemented by a more detailed analysis later on in our project. We will also analyse the feasibility and effectiveness of 'packages' of policy instruments and hybrid forms of instruments. Detailed inventories will be made of policy instruments for sustainable consumption in Europe, and case studies will be conducted of the most promising instruments.

\section{FROM POLICY OUTPUT TO POLICY OUTCOME}

In order to specify the links between policy outputs (concrete implementation of instruments) and policy outcomes (changes in consumer behaviour), we conducted a review of consumer research in economics, psychology, social psychology and sociology, integrative research on sustainable consumption ${ }^{26}$, as well as gender aspects of sustainable consumption.

Due to space constraints we can only present a summary of the most important results in the context of this paper. Literature suggests that policy instruments can target consumer behaviour directly and 
indirectly, the latter by changing the market environment or by modifying the social and physical environment of the consumer (Table 1).

Table 1. Target areas for policy influence on sustainable consumption.

\begin{tabular}{|c|c|c|}
\hline $\begin{array}{c}\text { Consumers / } \\
\text { individual citizens }\end{array}$ & Market environment & $\begin{array}{l}\text { Social and physical } \\
\text { environment }\end{array}$ \\
\hline $\begin{array}{l}\text { - } \quad \text { Ability and opportunity } \\
\text { - } \quad \text { Routines and habits } \\
\text { - } \\
\text { - } \\
\text { Cotivation and norms } \\
\text { ment }\end{array}$ & $\begin{array}{ll}\text { - } & \text { Prices } \\
\text { - } & \text { Product information } \\
\text { - } & \text { Consumption feedback } \\
\text { - } & \text { Market transparency } \\
\text { - } & \text { Availability of products and } \\
& \text { services } \\
\text { - } & \text { Use of government market } \\
& \text { power and example }\end{array}$ & $\begin{array}{l}\text { - } \text { Systems of provision } \\
\text { - Enabling infrastructures and } \\
\text { conditions } \\
\text { - Support for local sustainable } \\
\text { communities and social } \\
\text { groups }\end{array}$ \\
\hline
\end{tabular}

While these target areas are presented above separately, they are in fact strongly interlinked. It is more an issue of which part of the system is primarily targeted. Thus, we can identify mechanisms that focus primarily on the individual level, by trying to build up consumers' motivation and ability to 'do the right thing' by providing the appropriate information and incentives or disincentives. The initiatives can target the consumers' abilities and opportunities, routines and habits and/or motivation and internalized norms. They can also aim to build up confidence and empowerment, e.g., by providing feedback on the aggregated effects of many individuals' actions, or by supporting tendencies toward political consumerism ${ }^{27}$.

We can also identify mechanisms that aim to change the market environment of the consumer by changing the relative prices of products (e.g., via grants, taxes or by setting restrictions on production), but also by providing information about products, about consumers' purchases (feedback) or about the market in total (e.g., comparative environmental impacts of various products offered in the market). One can also argue that rules about marketing, advertising and product labeling influence market transparency by requiring or forbidding certain information to be provided. Finally, policies can aim to change the entire structure of the market (the availability of goods and services) by supporting R\&D in innovative solutions, setting minimum product standards, getting retailers to agree to drop certain products or promote certain other ones, or simply by banning certain products. Government can use its market power through green public procurement aiming to bring new products into the market. Where government also provides services, it can showcase new solutions under the auspices of these services, thus leading by example' and creating demand among private consumers.

Finally, the last row in Table 1 suggests that the ability to make use of these different mechanisms depends on timing and the use of 'windows of opportunity'28. This suggests that policy makers should 'bend' rather than try to 'break' trends 5 . All fields (consumption, market and infrastructures) have a certain inertia to them, and changes are difficult to accomplish. It is easier to try to influence developments that are already ongoing and have momentum than to try to stop them or to start new developments through individual policy instruments.

\section{FROM POLICY OUTCOMES TO SUSTAINABILITY IMPACTS}

Successful policies and policy measures should have an effect on consumption patterns and through the consumption patterns on overall sustainability. These impacts can occur in a variety of ways ${ }^{29}$ :

B Shifting consumption within a product group to less environmentally harmful products in the same product category.

B Shifting consumption from one product category to another. 
B Reducing the consumption of certain product categories or commodities such as energy, water, meat or petrol.

B Reducing overall consumption (as defined in monetary terms), which on an aggregate level would lead to a reduced share of consumption in gross domestic product (i.e., more savings and investments, less consumption), or to a decline in gross domestic product.

From a consumer perspective, we can also analyse changes in consumption in terms of changes in 'needs areas', i.e., in the way in which certain basic needs (such as nutrition) are fulfilled ${ }^{30}$. Needs areas represent grouped demands for goods and services. Changes toward sustainability can include a number of the previous changes, i.e., shifts to less harmful products, shifts to other product categories, or the reduction of the consumption of certain product categories.

Material flow analysis has beome a common approach to examining the impact of consumption patterns on the environment and sustainability ${ }^{31}$. Material flow analysis is a systematic assessment of the stocks and flows within a system: it connects the sources, pathways and final sinks of a material ${ }^{32}$. It can be conducted on different levels of aggregation (individual products, consumption categories, expenditure on consumption categories or time use of various household activities). Conventional life cycle assessment (LCA) is a special case of material flow analysis, which focuses on physical flows in the production-consumption chains, usually of individual products. Changes in consumption pertaining to entire needs areas (e.g., food and housing) are more readily modelled using a broader material flow analysis ${ }^{33}$. Shifts in consumption between different product categories and changes in the overall level of consumption are best modelled with economy-wide input-output models ${ }^{32}$. The EUPOPP project focuses on the needs area level, thus making material flow analysis the most appropriate approach.

The relationship between consumption patterns and sustainability effects is rarely linear. It is mostly indirect, mediated by the resulting impacts on production patterns. The more indirect it is, the more there is a possibility of confounding factors. We can identify a number of mediating chains, and exemplify then with impacts on greenhouse gases.

\section{Changes in consumption mediated by changes in production patterns}

There are some examples of relatively direct impacts, e.g., changes in disposal patterns. If consumers sort organic waste for composting, this has a direct impact on methane emissions (providing that waste is appropriately composted, resulting in carbon dioxide rather than methane emissions). Most changes in consumption patterns, however, have an effect on greenhouse gases via changes in production patterns. For example, if consumers substitute green electricity for the electricity mix of their current supplier, this should have an impact on the production of various kinds of electricity, and the ensuing greenhouse gas emissions. There are intervening variables, however: e.g. the impact depends on whether demand for green electricity exceeds the existing supply.

The changes in the effects from consumption to production and to greenhouse gases are not always linear. For example, if consumers reduce their demand for electricity, less electricity needs to be produced, resulting in less $\mathrm{CO}_{2}$ emitted from power plants. The amount of reductions in $\mathrm{CO}_{2}$ emissions is not constant, however, but also depends on the impact of the consumption reduction on the load shape. Usually, the reductions in $\mathrm{CO}_{2}$ emissions would be proportionally larger in the marginal/peak load than in the base load.

\section{Changes in consumption patterns mediated via changes in other consumption patterns (and then followed by changes in production patterns)}

Changes in the consumption patterns are often mediated into sustainability impacts via changes in other consumption patterns (and only thereafter via changes in production patterns and the resulting reductions in greenhouse gases). Such changes can offset part of the reduction in environmental impacts, and they are conventionally called rebound effects. $34,35,36$ 
For example, purchasing of more energy efficient appliances should lead to less consumption of electricity, eventually leading to less production of electricity, resulting in less $\mathrm{CO}_{2}$ from power plants. But there is an additional intervening variable here: As it is relatively cheaper to use more energy efficient appliances, they may be used more frequently (e.g., lights are left on). This is called a direct rebound effect. Usually, direct rebound effects for lighting are in the order of $10 \%{ }^{37}$, so part of the reduction is offset by increased use.

Additionally, changes in the consumption of an individual commodity, such as energy, can lead to unpredictable changes in the consumption of other commodities, with ensuing changes in production and greenhouse gases. For example, if we manage to reduce the demand for residential energy use via a successful campaign, and the price of energy remains constant, the consumers will have more money to spend on other things. The energy intensity of all other commodities is lower than that of energy, so the total demand for energy is reduced 30 , but not to the extent of the initial saving, because part of the savings accrued are offset by increased consumption of, e.g. recreational services. This type of rebound effects are called indirect rebound effects.

\section{Long-term structural changes in production and consumption patterns}

There are also changes that are mediated via long-term structural changes in production and consumption. Savings of energy and natural resources (and the ensuing reduction of $\mathrm{CO}_{2}$ ) are often at least partly offset by 'transformational' or 'enabling' effects, which are a further category of rebound effects 38 . This type of effect is most obvious in information, communication and transportation technologies. Efficiency advances in these technologies have enabled global communications, which have a self-reproducing effect of increasing the demand for more communications and transportation ${ }^{38}$. Another example of transformational effects is the introduction of the microwave oven, which is more energy-efficient for heating food than a conventional oven. Microwave ovens, however, have not replaced conventional ovens, but have rather engendered a totally new category of products (ready-to-heat microwave meals).

This discussion does not aim to imply that the gains from sustainable consumption policy measures are always offset by rebound effects. It is also possible to envisage the opposite kinds of positive spin-off effects (e.g. if consumers reduce their demand for energy or natural resources, they become more favourable to policy initiatives that increase the cost of energy and natural resources) ${ }^{39}$. Rather, the discussion suggests that close attention needs to be paid to intervening variables between changes in consumption patterns and the resulting effects on the environment, society and the economy. These intervening variables need to be analysed on a case-by-case basis, as they can be different for different kinds of policy measures and targets.

The EUPOPP aims primarily to use material flow analysis to identify the influence of changes in consumption patterns on other parts of the product life cycle (including dynamic effects such as increase or decrease in the demand for various factors of production). Influences of changes in individual consumption pattems on overall consumption patterns and influences of changes in products and technologies on overall consumption patterns will be addressed on a case-by-case basis.

The above discussion also suggests that the dynamic effects of sustainable consumption policies depend on overall developments in policies, institutions and the market at large. Productionconsumption systems are complex and interlinked in many ways. Thus, improvements in one part of the system may lead to a shift of impacts to another part. Piecemeal policy instruments may thus result in counterproductive effects, whereas consistent policies are likely to support each other and avoid counterproductive results ${ }^{30}$. Influencing society via sustainable consumption policies needs to be embedded in a broader and consistent set of policies in order to have the desired effects.

\section{DISCUSSION AND CONCLUSIONS}

In our conceptual framework, we have identified key pathways for evaluating and modelling the prospective impacts of policies to promote sustainable consumption. Our empirical approach for analysis is pre sented in Figure 1. 


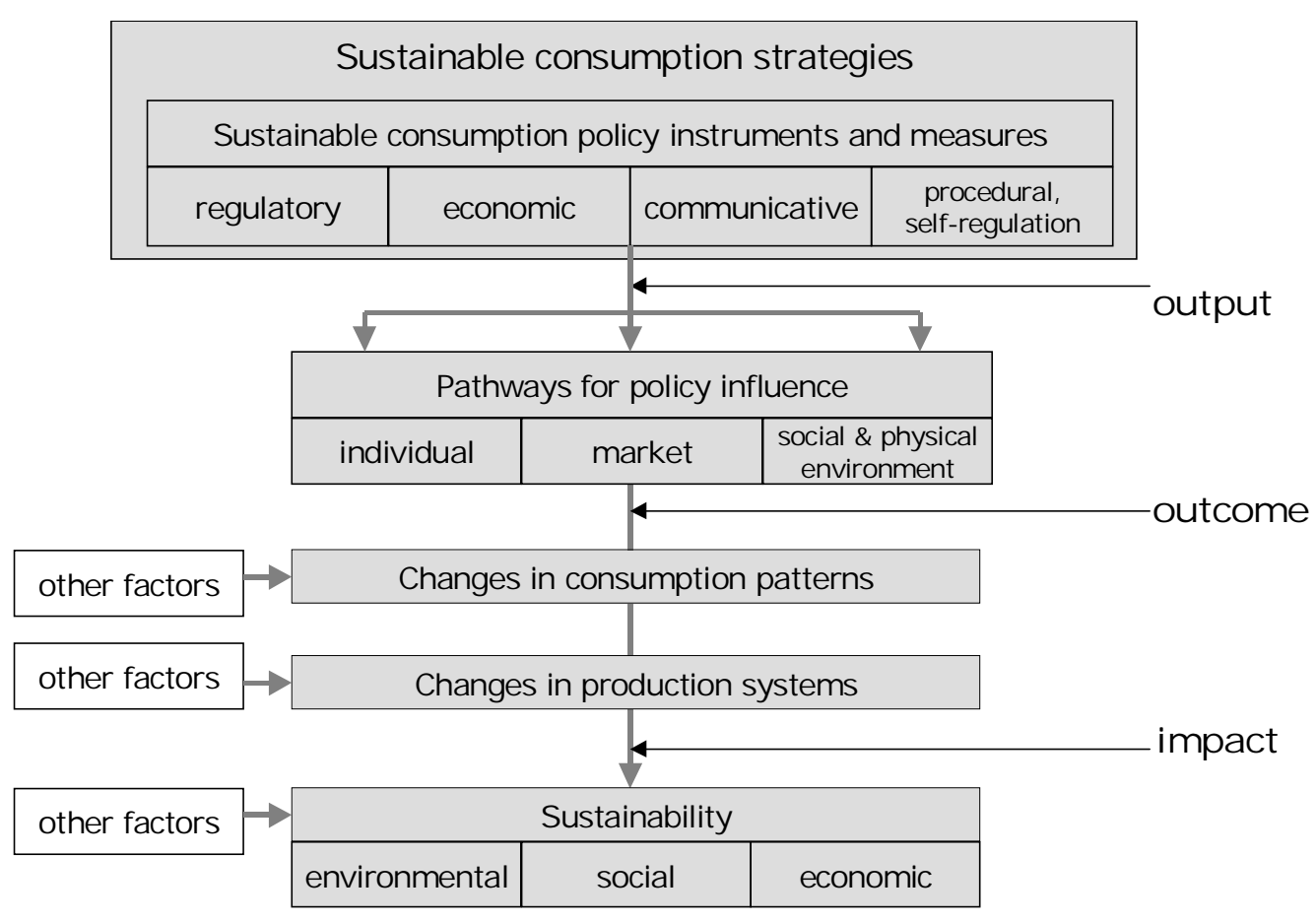

Figure 1. Three-step framework for connecting sustainable consumption policies to their sustainability impacts in the EUPOPP project.

We can use this framework, for example, to analyse and model the impact of a package of instruments to reduce the environmental impact of housing. Outputs and outcomes of effective instruments are analysed using policy analysis (who was reached, what behaviour changes were accomplished). Interviews and data on consumer behaviour and residential energy and resource consumption allow us to identify changes in consumption patterns. A careful analysis of trends and business-as-usual scenarios enables us to distinguish the impact of the selected policies from the impacts of other factors. Further, material flow analysis is used to identify changes in production systems (e.g. energy, construction, appliances), as well as the resultant impacts on selected sustainability indicators within and outside Europe. This analysis will allow us to provide much-needed advice for policy makers aiming to steer Europe on a path toward more sustainable consumption.

\section{REFERENCES}

1 World Summit for Sustainable Development (2002) J ohannesburg Plan of Implementation. Available http:// www.un.org/ esa/sustdev/documents/WSSD_POI_PD/English/WSSD_PlanImpl.pdf. Cited 6 ${ }^{\text {th }}$ April 2009.

2 EC (2008) Communication from the Commission to the European Parliament, the Council, the European Economic and Social Committee and the Committee of Regions on Sustainable Production and Consumption and Sustainable Industrial Policy Action Plan. Brussles 16.7.2008. COM (2008) 397 final. 12 p.

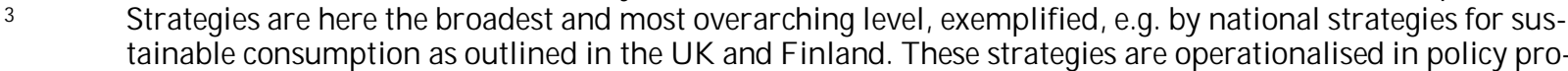
grammes consisting of a coherent set of policy instruments, usually including a time frame and plans for implementation. Finally, "policy interventions" refer to the actual implementation of policy instruments so as to change existing behavioural patterns (Weiss 1998: 7)

4 Tukker, A., Charter, M., Vezzoli, C., Sto, E. \& Munch Andersen, M. (2008) System Innovation for Sustainability 1. Perspectives on Radical Changes to Sustainable Consumption and Production. Sheffield: Greenleaf Publishing. $470 \mathrm{p}$.

5 Tukker, A. (2008) Conclusions: Change management for sustainable consumption and production. In Tukker, A., Charter, M., Vezzoli, C., Sto, E. \& Munch Andersen, M. (eds.). System Innovation for Sustainability 1. Perspectives on Radical Changes to Sustainable Consumption and Production. Sheffield: Greenleaf Publishing. pp. 406- 443. 
We define these impacts using the following sustainability indicators (1) Environmental: greenhouse gas emission, non-renewable primary energy, land use, agricultural biodiversity, raw materials, water use (2) Social: distributional effects on income/ living standards, gender equality (income/ living standards, time budget, gender labour market structure, employment, health (e.g. particulates) (3) Economic: costs to households, costs to society. See also UNEP DTIE (2008) Overview of International Organisation indicator sets. Available http:// www.unep.fr/ scp/ nap/ indicators/ international.htm.

Leeuw, F.L. (2003) Reconstructing Program Theories: Methods Available and Problems to be Solved. American J ournal of Evaluation Vol. 18, pp. 5- 20.

Vedung, E. (1997) Public Policy and Program Evaluation. Transaction Press. 336 p.

Bemelmans-Videc , M-L., Rist, R. \&Vedung, E. (1998) Carrots, Sticks and Sermons. Policy Instruments and their Evaluation. Transaction Publishers: New Brunswick, USA. 280 p.

Howlett, M. \& Ramesh, M. (2003) Studying public policy: Policy cycles and policy subsystems. Canada: Oxford University Press. 248 p.

Schönherr, N. (2008) Review of regulatory instruments. Öko-Institut e.V., November 18 2008, EUPOPP WP1. $18 \mathrm{p}$.

GTZ/ CSCP (2007) Policy Instruments for Resource Efficiency: Towards Sustainable Consumption and Production. Collaborative paper by German Technical Cooperation (GTZ), the UNEP/Wuppertal Institute Collaborating Centre on Sustainable Consumption and Production (CSCP) and the Wuppertal Institute, with support from the German Federal Ministry for Economic Cooperation and Development (BMZ). 120 p. Tukker , A., Mont, O. \&Lorek, S. (2008) Sustainable Consumption Policies Effectiveness Evaluation (SCOPE2). Final Report-Draft 7 October 2008. FP6 2005-SSP-5A. 18 p. Directive 2005/32/ EC.

Larcom, S., Smith, S. \& Swanson, T. (2008) Economic instruments and Sustainable Consumption: a review. UCL, November 18 2008, EUPOPP WP1. 20 p.

World Energy Council (2008) Energy Policies around the World: Review and Evaluation. 122 p.

Alcantud, A., Adell, A. \& Schaefer, B. (2008) Instrument type review: GPP. Ecoinstitut, November 182008 , EUPOPP WP1. 16 p.

Bremere, I. \& Fammler, H. (2008) Review of consumer information and education. BEF, November 18 2008, EUPOPP WP1.

Martiskainen, M. (2007) Affecting consumer behaviour on energy demand. Sussex: SPRU - Science and Technology Policy Research. 81p.

Aalto, K. (2008) Review of labels. NCRC, November 18 2008, EUPOPP WP1. 16 p.

Aalto, K., Heiskanen, E., Leire, C. \& Thidell, A. (2008) The Nordic Swan: From past experiences to future possibilities. TemaNord 2008:529. 168 p.

OECD (2002) Towards Sustainable Household Consumption? Trends and Policies in OECD Countries. Paris: OECD. $158 \mathrm{p}$.

Schmitt, K. \& Rogalla, F. (2008) Literature analysis of “other voluntary instruments”. Öko-Institut e.V., November 18 2008, EUPOPP WP1. 11p.

Ouchi, W.G. (1979) A Conceptual Framework for the Design of Organisational Control Mechanisms. Management Science Vol. 25, pp. 833-848.

Bruppacher, S.E. (2001) Umweltverantwortliches Handeln im Provathaushalt - Chancen und Grenzen der Selbstmodifikation. Dissertation Regensburg. 430 p.

Heiskanen, E. \& Schönherr, N. (2009) EUPOPP Work Package 1Deliverable 1.2: Conceptual Framework, Final Draft, April 2009. Öko-Institut and National Consumer Research Centre. Available http:// www.eupopp.net/. Cited 2nd May 2009.

Stø, E., Throne-Holst, H., Strandbakken, P. \&Vittersø, G. (2008) Review: a multi-dimensional approach to the study of consumption in modern societies and the potential for radical sustainable change. In Tukker, A., Charter, M., Vezzoli, C., Sto, E. \& Munch Andersen, M. (eds.). System Innovation for Sustainability 1. Perspectives on Radical Changes to Sustainable Consumption and Production. Sheffield: Greenleaf Publishing. pp. 234- 254.

Kingdon, J . W. (2003) Agendas, Alternatives and Public Policies. Second Edition, Addison-Wesley Educational Publishers Inc. $254 \mathrm{p}$.

Heiskanen, E., Halme, M., Jalas, M., Kärnä, A. \&Lovio, R. (2001) Dematerialization: the potential of ICT and services. Helsinki, Ministry of Environment: Finnish Environment 438. 240 p.

Wiegmann, K., Eberle, U., Fritsche, U. \& Hünecke, K. (2005) Umweltauswirkungen von Ernährung - Stoffstromanalysen und Szenarien. Darmstadt/ Hamburg: Öko-Institut. Diskussionspapier Nr. 7. 71 p.

Hertwich, E. (2005) Life Cycle Approaches to Sustainable Consumption: A Critical Review. Environmental Science and Technology Vol. 39, pp. 4673- 4684.

Brunner, P. \& Rechberger, H. (2003) Practical Handbook of Material Flow Analysis. CRC Press. 332 p. Wiegmann, K., Eberle, U., Fritsche, U. \& Hünecke, K. (2005) Umweltauswirkungen von Ernährung - Stoffstromanalysen und Szenarien. Darmstadt/Hamburg: Öko-Institut. Diskussionspapier Nr. 7. 71 p.

Schipper, L. (2000) On the rebound: the interaction of energy efficiency, energy use and economic activity. Energy Policy Vol. 28, pp. 351- 501.

J alas, M. (2001) Measuring dematerialization at the level of products. In Heiskanen, E., Halme, M., J alas, M., Kärnä, A. \&Lovio, R. Dematerialization: the potential of ICT and services. Helsinki, Ministry of Environment: Finnish Environment 438. pp. 93-106.

Herring, H. (2006) Rebound Effect. In Encyclopedia of the Earth. Last Updated: August 30, 2006. Available http:// www.eoearth.org/article/ Rebound effect. Cited 2nd May 2009. 
37 Greening, L.A., Sandstad, A.H. \& Difiglio, C. (2000) Energy efficiency and consumption - the rebound effect -a survey. Energy Policy Vol. 28, pp. 389-401.

38 See, e.g. Heiskanen, E., Halme, M., Jalas, M., Kärnä, A. \& Lovio, R. (2001) Dematerialization: the potential of ICT and services. Helsinki, Ministry of Environment: Finnish Environment 438. 240 p.

39 Heiskanen, E. \&J alas, M. (2003) Can services lead to radical eco-efficiency improvements? - a review of the debate and evidence. Corporate Social Responsibility and Environmental Management Vol. 10, pp. 186198. 